intriguing article by the late Kurt Lewin, a leader in sociological thought and technique as yet almost unknown in Britain. To an equilibrium economist his reduction of such social situations as unhappy marriages, restriction of industrial output or, aggressiveness among boys to an equation of conflieting forces must be interesting and flattering. Human Relations also contains a survey of prejudice in a seaside town, and studies of the civil resettlement of British prisoners of war, and of a scheme for residential management in treating difficult children. The theoretical essays are thus well balanced by articles descriptive of current procedures. Occasionally, as in an unnecessarily complicated account of a fairly simple experiment in industrial training, the writing is wordy and pedantic.

The wide field of contemporary social activity now being approached in the scientific mood is clearly illustrated in these current periodicals. Quite apart from their admirable American articles, Pilot Papers contain in the two numbers for June and September 1947 a much-needed analysis of bureaucrat behaviour, of B.B.C. 'third programme' listening and of the conception of progress in general (by Dr. Julian Huxley) and its practice in agriculture in particular. There are also first-hand experiences of service on a jury, the 'closed shop', and rent tribunal procedure. We look forward to further numbers of all these ventures in modern sociology. P. Sargant Florence

\section{NORTHERN IRELAND FISHING INDUSTRY DEVELOPMENTS DURING THE WAR YEARS}

$\mathrm{P}$

RIOR to the outbreak of the Second World War, the inhabitants of Northern Ireland exported to Grear Britain most of the fish they caught, and imported from Britain most of the fish that they ate. During the war years, however, the consuming public became much more dependent on their own locally caught fish and only surpluses were exported.

In a "Report on Sea and Inland Fisheries", recently published by the Government of Northern Ireland*, these and other war-time changes are reported. As no figures of production and trade exchange could be published during the War because of the statistical 'blackout', this report includes tables for the six-year period 1939-44.

The developments that took place in the Northern Ireland fishing industry during the years under review are indicated by the fact that herring catches in 1944 totalled 50,895 cwt. as compared with 39,467 cwt. in 1938 , and whiting catches rose from $17,061 \mathrm{cwt}$. in 1938 to no less than $64,619 \mathrm{cwt}$. in 1944. The total value of fish (excluding salmon) landed on the coast in 1944 was $£ 258,427$.

Taking all kinds into account, the quantities of sea fish landed in 1944 increased to approximately double the pre-war figure. The total number of fishing boats in Northern Ireland was 508 in 1944, a decrease of 51 boats compared with 1938. Motor boats, however, increased from 314 to 338 in this period, and vessels solely engaged in fishing increased from 109 to 149 in 1944. The number of men em. ployed in sea fishing increased from 898 to 1,031 ,

* Report on Sea and Inland Fisheries, 1942-1944. Pp. 20. (Belfast: H.M. Stationery Office, 1947.) 18. net. of which latter figure 555 were whole-time fishermen, the highest number to be so engaged since the year 1930. The chief factor in this increase in the number of fishermen was the main County Down fleet, which increased from 45 vessels in 1938 to 56 in 1944 .

The report states that the scheme of loans and conditional grants authorized in 1941, combined with greatly increased earnings by fishermen, gave the necessary incentive for the replacement of older craft by vessels of modern design. By the end of 1944, a substantial number of new craft designed for herring fishing and seine netting was either in commission or under construction in spite of war-time shortages. In the years covered by the report, loans exceeding $£ 24,000$ were advanced by the Ministry.

There is also a year-by-year review of inland fishing. Reference is made to the fact that in several hatcheries artificial propagation of salmon was carried out. The year 1943 was the best pollan season in Lough Neagh since 1927. High prices in crossChannel markets greatly helped to stimulate the activities of the freshwater fishermen. On account of the scarcity of fish in Great Britain, considerable impetus was given to the capture of coarse fish in rivers and lakes in Northern Ireland. In the Lough Erne district alone, the total exports of coarse fish in 1944 increased to almost a hundred tons.

\section{FORTHCOMING EVENTS}

\author{
(Meetings marked with an asterisk * are open to the public)
}

Monday, March 22

Assoclation of APPLIED Brologists (in the Botany Lecture Theatre, Imperial College of Science, South Kensington, London, S.W.7), at 11 a.m.-Discussion on "Biological Aspects of Water Pollution"."

RoYal Geographical Society (at Kensington Gore, London, S.W.7), at 5.30 p.m.-Dr. K. M. Strom: "The Geomorphology of Norway".

INSTTTUTION OF THE RUBBER INDUSTRY, MANCHESTER SECTION (at the Engineers' Chub, Albert Square, Manchester), at 6.15 p.m.Mr. T. J. Meyrick and Dr. J. T. Watts: "Polyisocyanates-some Applications in Bonding".

\section{Tuesday, March 23}

Manchester Geographical Society (in the Geographical Hall, St. Mary's Parsonage, Manchester), at 6.30 p.m.-Miss K. Speight: "Sicily, the Garden of the Mediterranean".

TEXTILE INSTITUTE, LONDON SECTION (at the Royal Society of Arts, John Adam Street, Adelphi, London, W.C.2), at 6.30 p.m.Mr. F. Courtney Harwood: "The History and Science of Washing". SHEFFIELD METALLURGICAL ASSociation (at 198 West Street Sheffield, at 7 p.m.-Dr. N. P. Allen: "Some Techniques and Results in Metallurgical Research".

\section{Wednesday, March 24}

BRITISH SOCIETY FOR INTERNATIONAI BIBLIOGRAPHX (at the Institution of Electrical Engineers, Savoy Place, Victoria Embank ment, London, W.C.2), at 2.30 p.m.-Users' Questions on the Universa Decimal Classification Answered.

PALESTINe HodSE (at 18 Manchester Square, London, W.1), at 5.45 p.m.-Dr. Clay Lowdermilk: "The Jordan Valley Scheme"." ROYAL MICROSCOPICAL SOCIETY, INDUSTRIAL MICROSCOPY SECTION (at B.M.A. House, Tavistock Square, London, W.C.1), at 6 p.m.Mr. H. L. Shipp : "The Microscopy of Food".

SOCIETY OF Chemical INDUSTRY, NUTRITION PANEL OF THE FOOD GrodP (joint meeting with the BRITISH DIETETIO ASSOCIATION, at th Chemical Society, Burlington House, Piccadilly, London, W.1), at 6 p.m.-Dr. D. P. Cuthbertson and Miss R. M. Simmonds: "Special Dietary Requirements in Sickness and Convalescence".

Socinty of DYers and Colodrists, Midlands Section (at the Victoria Station Hotel, Nottingham), at 7 p.m.-Mr. G. H. Lister : "The Absorption of Acid and Chrome Dyes by Wool";

CHEMICAL SOCIETY, ABERDEEN SECTION (joint meeting with the LOCAL SECTIONS of the ROYAL INSTTTUTE OF CHEMISTRY and the SOCIETY OF CHEMICAL INDUSTRY, at Marischal College, Aberdeen), at 7.30 p.m.-Prof. E. E. Turner : "Some Stereochemical Problems".

\section{Thursday, March 25}

BRITish Institution of Radio Enginkers, Midland Section (at the Technical College , The Butts, Coventry), at 6.30 p.m.- Mr. and Time Delay of Transmission Networks". 